Pneumoconiosis Medical Panel, Cardiff, for referral of cases; to Messrs. F. U. Oldham and G. Berry for statistical advice; and to Miss E. Dawkins for technical assistance.

\section{REPERENCES}

Brasseur, L. (1963). L'exploration fonctionnelle pulmonaire dans la pneumoconiose des houilleurs. Brussels.

Cotes, J. E. (1965). Lung Function. Oxford.

Englert, M., and De Coster, A. (1965). F. franç. Méd. Chir. thor., 19, 159.

Gaensler, E. A., Hoffman, L., and Elliott, M. F. (1960). Poumon, 16,
International Labour Office (1959). Occupational Safety and Health, 9. - (1966). Occupational Safety and Health Series, No. 6. Geneva.

Meade, F., Saunders, M. J., Hyett, F., Reynolds, J. A., Pearl, N., and Cotes, J. E. (1965). Lancet, 2, 573 .

Medical Research Council (1960), Brit. med. 7., 2, 1665

Nica (1965). Lancet, 1, 775 .

Nicaise, R., Vereerstraten, J., and de Clercq, F. (1967). Proc. roy. Ned. Tuberc. Ass., Selected Papers, 10, 70.

Podlesch, I., Stevanowic, M., and Ulmer, W. T. (1966). Med. thorac. (Basel), 23, 283.

Rossiter, C. E., Rivers, D., Bergman, I., Casswell, C., and Nagelschmidt, G. (1967). Inhuled Particles and Vapours, vol., 2 , edited by C. N. Davies, p. 419. Oxford.

Wagner, J. C., and McCormick, J. N. (1967). F. roy. Coll. Phycns, 2, 49.

\title{
Outbreak of E.C.H.O. Virus Type 30 in a General Practice
}

\author{
D. H. IRVINE,* M.D. ; A. B. H. IRVINE,* M.B., CH.B. ; P. S. GARDNER, † M.D., DIP.BACT.
}

Brit. med. F., 1967, 4, 774-776

For many years E.C.H.O. viruses have been known aetiological agents in human disease, particularly aseptic meningitis; examples include type 4 (Chin et al., 1957), type 6 (Kibrick et al., 1957), and type 9 (Tyrrell and Snell, 1956). One of the latest to be linked with aseptic meningitis is type 30, described in Scotland originally as the "Frater virus" (Duncan, 1960). A virus now known to be identical was described in the United States as the "Bastianni virus" (Plager and Decher, 1963).

E.C.H.O. virus type 30 was first incriminated in illness in this country in 1950-60 and has been encountered only occasionally between 1960 and 1964 (Grist and Bell, 1967). Current information on symptomatology is based on isolated cases seen in hospital practice. In this communication we describe an outbreak of a febrile illness observed in a general practice for which there is evidence that the causal agent may have been E.C.H.O. virus type 30 .

\section{Present Investigation}

The practice has two principals and a list of approximately 5,140 patients. Though the majority of patients are resident in Ashington, a colliery town with a population of 28,000 people, a considerable number live either in the adjacent urban

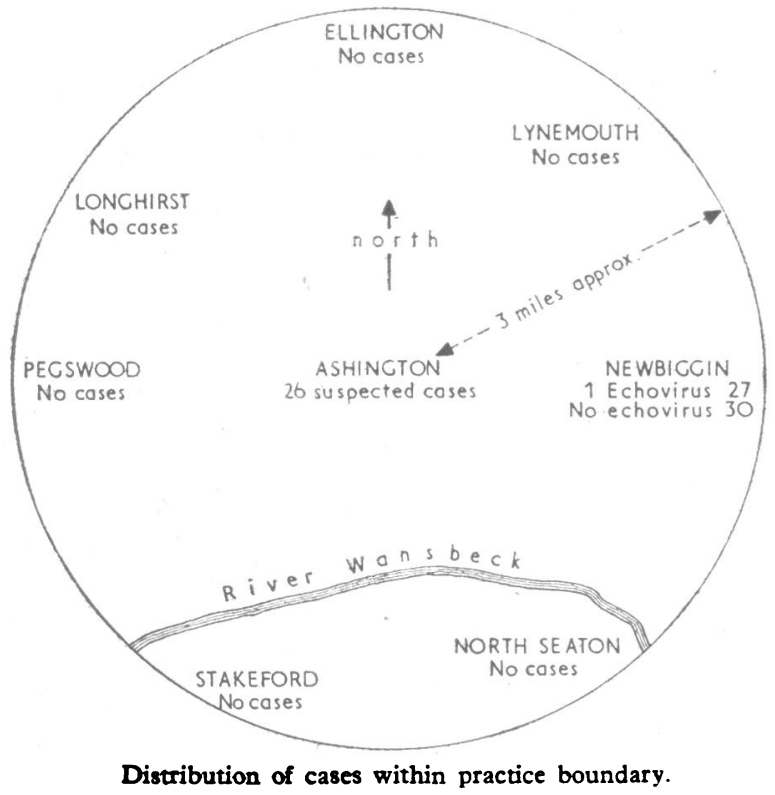

Distribution of cases within practice boundary area of Stakeford, which lies on the opposite bank of the River Wansbeck, or in one of five near-by villages. The practice boundary is within a 3 -mile $(5-\mathrm{km}$.) radius from the centre of Ashington (see Fig.).

The outbreak began in mid-June 1966, when two children presented within a day or two of each other a clinical picture suggestive of aseptic meningitis. Faeces were sent for laboratory examination, but before the results became available two further cases were seen, though the illness was less severe. As it was now evident that an unusual illness was prevalent in the practice, arrangements were made to widen the field of study. It was agreed to observe any new patients presenting with a febrile complaint in whom it was impossible initially to make a definite diagnosis or who had symptoms similar to those seen in the earlier cases. This system of screening was thought desirable since no pathogen had been identified at that stage. It was anticipated that in some cases an alternative diagnosis would emerge ; in the event these cases, with one exception, were grouped together before individual laboratory results became available (group C below).

Laboratory Methods.-Specimens of stool were taken from all suspected cases. On arrival in the laboratory these specimens were emulsified in a $10 \%$ suspension and centrifuged. Then 0.2 and $0.1 \mathrm{ml}$. respectively were inoculated into two monkeykidney and two Hep. 2 tissue culture tubes. Tissue culture tubes were examined daily; suspected virus agents were passaged into fresh tubes and identified by neutralization against specific antisera. Details of the laboratory procedures used have been described (Gardner et al., 1961; Gardner and Cooper, 1964).

\section{Results}

Altogether 46 patients were examined in the period from 10 June to 22 August. It has been found convenient to classify them into three groups as follows:

Group A: Twenty-two patients (9 female, 13 male) with a symptom pattern peculiar to the outbreak in whom E.C.H.O. virus 30 was isolated from faeces.

Group $B$ : Four patients (all female) with similar clinical features as group $A$ in whom no virus was found in faeces.

Group C: Twenty patients ( 7 female, 13 male) presenting with a febrile malaise and later shown to be suffering from another condition. E.C.H.O. virus type $\mathbf{3 0}$ was not identified in their faeces.

* General Practitioner, Ashington, Northumberland.

t Consultant Virologist, Royal Victoria Infirmary and University of Newcastle upon Tyne. 
For further analysis groups $\mathrm{A}$ and $\mathrm{B}$ have been added together. Table I shows the relation of the outbreak to time; the apparently sudden onset was noted by other practitioners in the town. The end-point appears to have been reached as quickly, since no patients with a typical history were seen after 22 August. In Table II the age distribution of those with suspected E.C.H.O. virus 30 infection is compared with the overall practice population. The attack rates reported should be viewed with caution, as a numerically undetermined fraction of the total practice list is distributed in the outlying villages (see Fig.), where no cases were seen. Thus the attack rates given are probably an underestimate of the true rate in Ashington itself (Table II).

TABLE I.-Relation of Outbreak to Time

\begin{tabular}{l|c|c|c|c}
\hline & 20 June & 10 July & 30 July & 20 Aug. \\
\hline No. of cases in groups A and B & 4 & 9 & 10 & 3 \\
\hline
\end{tabular}

TABLE II.-Age Distribution of Cases and Practice Population

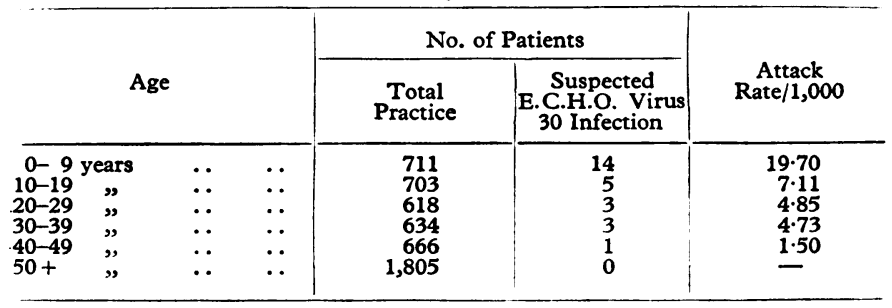

The geographical distribution of cases is interesting (see Fig.). Clearly the outbreak was extremely local, since no cases were reported in outlying areas of the practice despite the very short distances involved. In four instances two people in the same household were affected. Similarly, two patients in group $B$ were on friendly terms and in social contact with two others in group A. They, in turn, were neighbours of two additional families in group A, which suggests that groups A and B may have a common causal agent.

Cases in group $\mathbf{C}$ were distributed randomly throughout all geographical areas of the practice.

It may be helpful to consider the main clinical groups in greater detail.

\section{Groups A and B}

Both in children and in adults the principal symptoms included headache, malaise, muscle pains, vomiting, and abdominal pain. The duration of complaint varied in individual patients from one to seven days, with an average of three days. Invariably the illness was of rapid onset-a period of two to three hours-and caused most distress in the first 24 hours.

Headache and muscle pains were experienced by all patients; indeed, headache was often severe, and it was the commonest presenting symptom. Vomiting (18 cases) was often limited to the first day. Colicky abdominal pain (11 cases) was not associated with a change in bowel habit but gave rise to concern in two patients when generalized abdominal tenderness and guarding were observed for several hours. Photophobia (eight cases) never persisted more than 18 hours.

Examination usually revealed only tenderness of muscle on palpation and a temperature rising above $100^{\circ} \mathrm{F}$. $\left(37.8^{\circ} \mathrm{C}\right.$.) (19 cases). Neck rigidity (four cases) was marked in the first two patients of the series, while a fleeting macular rash was seen once-otherwise the skin was not involved.

Illustrative case summaries from group A are given.

Case 1.-A boy aged 11 years gave a three-day history of increasingly severe headache, photophobia, and nausea. Examina- tion at the first visit showed no abnormal signs except a pyrexia of $101.2^{\circ} \mathrm{F}$. $\left(38.4^{\circ} \mathrm{C}\right.$.) ; later that day he became sick, while the headache was unabated. Neck rigidity and Kernig's sign were then present. Thereafter the clinical course was one of rapid improvement to full recovery within two days.

Case 2.-A girl aged 7 years attended school one morning feeling perfectly well, but had to return home at lunch-time because she suddenly developed intense headache and was unable to focus on the blackboard properly. In the afternoon she began to vomit. Examination revealed a temperature of $101.8^{\circ} \mathrm{F} .\left(38.8^{\circ} \mathrm{C}\right.$.), raised pulse rate, and slight neck rigidity. By evening the headache was subsiding; the following morning the child had fully recovered.

Case 9.-A married woman aged 33 became ill suddenly one afternoon complaining of intense headache, malaise, nausea, and quite severe abdominal pain. There was generalized muscle-aching. The following day she requested her doctor to visit because of intense pain in the right loin and right iliac fossa. Headache was still present, now with photophobia. Abdominal examination revealed marked tenderness and guarding in the right iliac fossa, and a diagnosis of appendicitis was considered. Next day a generalized macular rash was present for a few hours; the patient felt better, as both headache and abdominal pain were subsiding. Two days later, apart from slight weakness, recovery was complete.

Case 18.-A boy aged 9 years gave a four-day history of intermittent malaise, nausea, headache, and abdominal colic. On the day of consultation his headache had worsened and he said that light hurt his eyes. The only abnormal physical sign was a temperature of $98.6^{\circ} \mathrm{F}$. $\left(37^{\circ} \mathrm{C}\right.$.), though his mother had recorded a higher temperature earlier. He returned to normal health two days later.

\section{Group C}

This group comprises patients presenting with a nonspecific febrile illness, later, with four exceptions, to develop manifestations of other infections. Eight patients had upper respiratory infections or tonsillitis. Four with watery diarrhoea showed none of the other main clinical features described in groups $A$ and B. A urinary infection in one child was confirmed by laboratory examination, and acute appendicitis was found at operation in an adult. The firm diagnosis of infection with E.C.H.O. virus 9 was made in another child and later supported by laboratory findings. E.C.H.O. virus 27 was isolated from a boy who later complained of headache; he lived in an outlying village thought to have escaped the outbreak of E.C.H.O. virus 30. Finally, there were the four patients in whom diagnosis was never made. All were young children, feverish one day and better the next, with no localizing symptoms or signs whatsoever.

\section{Discussion}

It is often tempting to suggest a cause-and-effect relationship when viruses are identified in patients presenting with an otherwise inexplicable febrile illness. However, there is evidence that the finding of E.C.H.O. virus 30 in this series is of aetiological significance. Thus the outbreak began at a time of year when overt infection with E.C.H.O. virus is known to be most common. Typically, children are principally affected, as we found. Furthermore, the cardinal symptoms described in suspected cases (groups A and B) differ little from those in illness caused by other E.C.H.O. viruses (Sanford and Sulkin, 1959) and contrast sharply with the diverse patterns in group C, with the exception of the boy excreting E.C.H.O. virus 27.

The precise geographical localization of the outbreak, the first to be described linked with E.C.H.O. virus 30 so far as we know, is reminiscent of another attributed to E.C.H.O. virus 9 which was confined to a new residential estate in North-east England (Wright et al., 1961).

Our findings suggest that, though E.C.H.O. virus 30 has been found only sporadically over the last six years, it is not a new virus and adults have an immunity to it. 


\section{Summary}

An outbreak of a febrile illness confined to a local geographical area within a general practice is described. E.C.H.O. virus 30 was isolated from faeces in a majority of cases. The illness was of rapid onset but lasted only a few days, and the principal symptoms included headache, muscle pains and malaise, vomiting, colicky abdominal pain, and photophobia. Evidence that E.C.H.O. virus 30 was of aetiological significance in the series is discussed. Although E.C.H.O. virus 30 has been found only sporadically over the last six years, the results suggest that it is not a new virus and that adults have an immunity to it.
We are indebted to the technical staff of the department of virology of the Royal Victoria Infirmary for their help.

\section{REFERENCES}

Chin, T. D. Y., Beran, G. W., and Wenner, H. A. (1957). Amer. F. Hyg., 66, 70.

Duncan, I. B. R. (1960). Lancet, 2, 470.

Gardner, P. S., and Cooper, C. E. (1964). F. Hyg. (Lond.), 62, 171.

Wright, A. E., and Hale, J. H. (1961). Brit. med. F., 2, 424.

Grist, N. R., and Bell, E. J. (1967). Hlth Bull. (Edinb.), 25, 18.

Kibrick, S., Meléndez, L., and Enders, J. F. (1957). Ann. N.Y. Acad. Sci., 67, 311

Plager, H., and Decher, W. (1963). Amer. F. Hyg., 77, 26.

Sanford, J. P., and Sulkin, S. E. (1959). Nerw Engl. F. Med., 261, 1113. Tyrrell, D. A. J., and Snell, B. (1956). Lancet, 2, 1028.

Wright, A. E., et al. (1961). Newc. med. F., 27, 13.

\title{
Calf Muscle Denervation for Intermittent Claudication*
}

\author{
N. V. ADDISON, $\dagger$ M.B., F.R.C.S.
}

Brit. med. F., 1967, 4, 776-778

It is now a well-established fact that the ideal treatment for femoropopliteal occlusions which cause intermittent claudication in the calf is a bypass graft. An autogenous saphenous vein is undoubtedly the best type of graft to use with good and lasting results (Darling et al., 1967). The indications for inserting a graft usually depend on the individual surgeon, who may operate for intermittent claudication which is not particularly disabling. Others may limit the procedure to those with severe claudication, rest pain, or impending gangrene (Shucksmith and Addison, 1962). The reversed saphenous vein bypass graft is usually taken from the common femoral to the distal popliteal artery behind or below the knee joint. The problem arises when the distal popliteal artery is grossly diseased or totally blocked. Under these circumstances it may be possible to take the graft to the posterior tibial or peroneal arteries if the saphenous vein is left in situ. If both distal popliteal and tibial vessels are unsuitable for grafting then only palliative treatment can be considered. Claudication can be relieved or the claudication distance increased by inactivation of the calf muscles where the pain develops. Two operations can be performed to effect this inactivation, one by Achilles tenotomy (Boyd and Bloor, 1960) and the other by denervation of the calf muscles.

If these muscles are paralysed the patient learns to use other muscles, including the hamstrings, when walking. Learmonth and Slessor (1952) describe this procedure of myoneurectomy and claim that patients obtain a walking distance some five times greater than preoperative distances.

If the distal vessels are blocked and there is severe rest pain in the foot or calf then an above-knee or Gritti-Stokes amputation may be necessary, though a lumbar sympathectomy is well worth trying, especially if pain is relieved by a medical sympathectomy (Martin, 1963). Obviously rest pain cannot be relieved by inactivation of the calf muscles, but if it is localized to a small area in the foot, treatment by a selective peroneal or anterior tibial neurectomy may help.

I have adopted the method of calf muscle denervation for patients with popliteal or tibial occlusions, and for some older patients with calf pain, as an alternative to a bypass graft. This

\footnotetext{
- Based on a lecture given at the invitation of the Professor of Surgery, Jefferson Medical College, Philadelphia, U.S.A., on 25 April 1967. t Consultant Surgeon, Royal Infirmary, Bradford.
}

paper is based on the first 40 denervations carried out during the past four years.

\section{Cause of Ischaemic Pain in Calf Muscles}

The cause of intermittent claudication is a relative anoxia of the muscles, and the importance of this anoxia was shown by Pickering and Wayne (1934). They found that by exercising muscles of an anaemic subject with no evidence of arterial disease characteristic pain of intermittent claudication could be produced. The clinical experiments of Lewis (1932) indicate that the direct cause of the pain is not oxygen lack itself but the stimulation of sensory nerves by the metabolic products of muscular activity. When the blood supply is inadequate and oxygenation therefore deficient, metabolic products accumulate. Lewis referred to the pain stimulus as "factor P." The nature of the chemical pain factor is unknown but is probably acid, and ingestion of sodium bicarbonate was found to increase the amount of exercise required to cause pain.

\section{Nerve Supply of Calf Muscles}

In a so-called motor nerve supplying a limb muscle at least 30 to $40 \%$ of the fibres are sensory in function and have their cell bodies in the dorsal root ganglia of the segmental nerves.

The endings of the afferent fibres in striated muscle vary a great deal in structure. The simplest ones are very fine nonmyelinated nerve fibres with no specific ending. Some run in perivascular plexuses, and others are found in connective tissue, and it has been suggested that these are pain fibres (Bowden, 1960).

The medial popliteal nerve, arising from the fourth and fifth lumbar nerves and the first, second, and third sacral nerves, supplies the two heads of the gastrocnemius and the soleus. In the popliteal fossa it is concealed at first by the semimembranosus and other hamstring muscles. It passes superficial to the popliteal vessels from the lateral to the medial side, and is thereafter found deep to the popliteus muscle under cover of the gastrocnemius and plantaris. Two branches arise in the fossa, one for each head of the gastrocnemius, and usually enter these muscles at the borders of the popliteal fossa. A nerve for 